SERI /TP-623-643.

UC CATEGORY: UC $-61 \mathrm{C}$

\title{
conf-800604-- 26
}

EFFECTS OF TEMPERATURE AND INTENSITY ON THERMODYNAMIC LIMITS FOR EFFICIENCIES OF PHOTOCHEMICAL CONVERSION OF SOLAR ENERGY

ROSEMARY V. BILCHAK

JOHN S. CONNOLLY

SOLAR ENERGY RESEARCH INSTITUTE

JAMES R. BOLTON

UNI VERSITY OF WESTERN ONTARIO

JUNE 1980

To BE PRESENTED AT THE

AS/ISES 1980 ANNUAL

MEETING, PHOENIX, ARIZ.,

JUNE 2-6, 1980

PREPARED UNDER TASK NO. 3325.30

\section{Solar Energy Research Institute}

A Division of Midwest Research Institute

1617 Cole Boulevard

Golden, Colorado 80401

Prepared for the

U.S. Department of Energy

Contract No. EG-77-C-01-4042 


\section{DISCLAIMER}

This report was prepared as an account of work sponsored by an agency of the United States Government. Neither the United States Government nor any agency Thereof, nor any of their employees, makes any warranty, express or implied, or assumes any legal liability or responsibility for the accuracy, completeness, or usefulness of any information, apparatus, product, or process disclosed, or represents that its use would not infringe privately owned rights. Reference herein to any specific commercial product, process, or service by trade name, trademark, manufacturer, or otherwise does not necessarily constitute or imply its endorsement, recommendation, or favoring by the United States Government or any agency thereof. The views and opinions of authors expressed herein do not necessarily state or reflect those of the United States Government or any agency thereof. 


\section{DISCLAIMER}

Portions of this document may be illegible in electronic image products. Images are produced from the best available original document. 


\author{
Printed in the United States of America \\ Available from: \\ National Technical Information Service \\ U.S. Department of Commerce \\ 5285 Port Royal Road \\ Springfleld, VA 22161 \\ Price: \\ Microfiche $\$ 3.00$ \\ Printed Copy $\$ 4.00$
}

\begin{abstract}
NOTICE
This report was prepared as an account of work sponsored by the United States Government. Neither the United States nor the United States Department of Energy, nor any of their employees, nor any of their contractors, subcontractors, or their employees, makes any warranty, express or implied, or assumes any legal liability or responsibility for the accuracy, completeness or usefulness of any information, apparatus, product or process disclosed, or represents that its use would not infringe privately owned rights.
\end{abstract}


Presented at:

\author{
1980 Annual Meeting \\ American Section \\ International Solar Energy Society \\ Phoen ix, Arizona \\ June $2-6,1980$
}

Paper $\# 604(B-1-2)$

FEFECTS OF TEMPERATURE AND INTENSITY ON THERMODYNAMIC LIMITS EOR EFFICIENCIES OF PHOTOCHEMICAL CONVERSION OF SOLAR ENERGY

\author{
Rosenary V. Bilchak and John S. Connolly \\ Chemical and Blological Conversion Division \\ Solar Energy Research Institute* \\ Golden, Colorado 80401 U.S.A.
}

\author{
James R. Bolton \\ Photochemistry Unit \\ University of Nestern Ontario \\ London, Ontar1o $\mathrm{N} 6 \mathrm{~A} 5 \mathrm{~B} 7$, Canada
}

\section{INTRODUCTION}

The subject of thermodynamic 11 mits on photochemical conversion of light to work has been of considerable interest for over twenty vears. Recently, Ross and Hsiao (1) calculated quantum conversion efficiencies for solar radiation at air mass zero (AMO). Bolton (2) later extended this treatment to A:11.2 solar Elux and also considered some kinetic as well as thermodynamic limitations. In this paper we apply these methods to a variety of solat intensities and absorber temperaturcs. We also examine improvements in efficlency which can be obtained by using sustems with several absorbers of different effective band-gap wavelengths. The results, which are applicable to photovoltalc as well as to photochemical and photoblological conversion devices, represent absolute (i.e., theal) upper llmits on conversion efflciencies, analogous to Carnot efficiencies of heat engines.

\$11 direct (t.e., quantum) conversion devices are threshold devices in that only photons with wavelengths up to that of the band-gap can he absorbed and converted to useful wor'x. 'Ne assume that the excited electronic state created by absorption of a photon, whether in a semiconductor or in a photochenical system, has a sufficlently long lifetime ( $>$ l ps) that the excited state bocomes Ehernally pquilihrated with les environment. This assumpion carries two innsequences: first, the energy of the piroton in excess of the band-gap is lost as heat; and second, the excited state loses all "remory" of the nature of the exciting radiation. Hence, only the flux of the absorbed procons is important.

Ve have also carried out calculations for two-photon processes (i.e., two discrete absorbers) over a liniced range of temprature-intensicy combinations. Finally,

*A division of Yidwest Research Institute. Joerated for the U.S. Departmenc of Energy under Contrace $5 G-77-C-01-4042$. we have extended the treatment to calculate the optimum wavelengths for multiphoton cases $(3<n<8)$ at fixed temperature and intensity.

\section{METHOD}

The equations derfued by Ross and Hslao ( 1 ) were Incorporated into a BASIC software routine written for the Hewlett-Packard 9845-S desk-top computer system. The program was configured for variation of solar intensity from 1 to $10^{4}$ suns at decadic intervals and absorber temperatures from 300 to $500 \mathrm{~K}$ in $50 \mathrm{~K}$ steps. As in Bolton's studles (2), the solar flux data of Böer (3) ( $M M 1.2$, "T/S") were used for all of these calculations. It should be noted, howcver, that Böer's spectra were computed using water-vapor absorption data which conflict with more recent models (4). This discrepancy creates a problem in the calculated solar spectrum in the region between 850 and $900 \mathrm{~nm}$. Unfortunately, no reliable experimental solar spectra are currently available for comparison, so we have assumed that Böer's data yield a reasonable approximation to an dill.2 solar spectrum.

The maxinum fraction of solar power which can be converted to chemical energy $\left(n_{p}\right)$ is the optimal energy storage rate (Eq. 12, Ref. 2) divided by the incident power Integrated over the total solar spectrum. From these relationships, one can derive the [ulctivod dependence of $n$ on intensity and temperature. The effects of these parameters were calculated for two-photon systems using the same assumptions as Bolton (2) for perfect, discrete absorbers. For each factor of 10 increase in solar intensity, we apbitrarily chose a 50 k temperature increment, using intial values of 1 sun and $300 \mathrm{k}$.

Starting at $300 \mathrm{~nm}$, the wavelengths of the first $\left(\lambda_{1}\right)$ and second $\left(\lambda_{2}\right)$ photons were lncremented according to the Büer spectrum (3) through $1500 \mathrm{~nm}$, with the constraint $\lambda_{2}>\lambda$. The output consists of the wavelengths Eor both photons and the corresponding power efficlencies $\left(n_{p}\right)$. For the nultiphoton calculations, the method of Davidon (5) for 
optimization of a smooth function involving many parameters was programmed into a CDC Cuber $170 / 720$ computer. The program yields wavelength combinations for up to 8 photons that optinize the fraction of solar power which can be converted. For these calculations, the intensity and temperature were held constant at 1 sun and $300 \mathrm{~K}$, respectively. As in the case of the single-photon caleulations for these same conditions, our mulziphoton results agree with the corresponding calculations of Bolton (2).

$A$ word of caution in 1nterpreting results from this program: The optimization routine finds only local maxima and is thus extremely sensltive to the starting conditions, espe:ially for $n>5$. The dimension of the opt $1-$ mization search is given by the number of photons, and each added dimension increases the "nolse" in the area of the absolute maximum. Accordingly, for each value of $n>5$, we carlied out 4-5 optimizations with varying initlal parameter estimates and chose from these the wavelength coinbination ylelding the highest value of $n_{p}$.

\section{RESULIS ANO DISCUSSION}

\subsection{Temperature-Intensity Combinations}

In general, the calculated thermodynamic (i.e., power) efficiencles for single-photon processes are a linear function of the logatithm of intensity at constant semperature and decrease Innearly with increasing temperature at fixed intensity (Table 1). The advantage of utilizing

\section{TABLE 1}

Maximum Thermodynamic Efficlencies (singlephoton) for AMl.2 Solar Radiation at Varlous Intensities and Absorber Temperatures

$(\lambda \simeq 840 \mathrm{~nm})$

\begin{tabular}{|c|c|c|c|c|c|}
\hline \multirow{2}{*}{$\begin{array}{l}\text { Intensity } \\
\text { (suns) }\end{array}$} & \multicolumn{5}{|c|}{ Absorber Tenperature (K) } \\
\hline & 300 & 350 & 400 & 450 & 500 \\
\hline $1 \frac{1}{10}$ & $\begin{array}{l}32.3 \\
34.1\end{array}$ & $\begin{array}{l}30.2 \\
32.3\end{array}$ & $\begin{array}{l}28.1 \\
30.5\end{array}$ & $\begin{array}{l}26.1 \\
28.7\end{array}$ & $\begin{array}{l}24.0 \\
26.9\end{array}$ \\
\hline $10^{2}$ & 35.9 & 34.4 & 32.3 & 31.3 & 29.8 \\
\hline $10^{3}$ & 37.7 & 36.5 & 35.2 & 34.0 & 32.7 \\
\hline 1$)^{4}$ & 39.5 & 38.5 & 37.6 & 36.7 & 35.7 \\
\hline
\end{tabular}

concentrators for single-photon conversion devices to increase the intensity of 1ncident radtation will be directly affected by the cemperatilu lacrease incurred in the process; vence, $i f$ the latensity were increased by a factor of $10^{3}$, the net gain in theoretical efflclency would be negligible if the absorber temperature were on the order of $500 \mathrm{~K}$.

\subsection{Two-Photon Systems}

As shown by Bolton (2), absorption of multiple photons of different wavelengths can also increase the theoretical power efficlency of a quantum conversion device. Table 2 lists the effective wavelengths for maximum $\eta_{0}$ with varying temperatures and intengities, and illustrates that the optimal wavelength comblation for the two effective bandgaps is relatively insensitive to either absorber temperature or incident solar intensity. The maximum efficlency, however, is more strongly dependent on Intensity than on temperature, at least for the 11 mited range of conditions examined. As in the case of single band-gap systems, our calculations show that each $50 \mathrm{~K}$ temperature Increment offsets the efficlency gain of a 10-fold increase of intensily. It would be interesting to extend this study to actual values of absorber temperatures experienced under concentrated solar radfation.

TABLE 2

Thermodynamic Efficlencles for Optimal Combinations of Two Absorber Navelengths at A:11.2

\begin{tabular}{ccccc}
\hline $\begin{array}{c}\text { Intensity } \\
\text { (suns) }\end{array}$ & Temperature & \multicolumn{3}{c}{ Efficlency } \\
\hline 1 & $(\mathrm{~K})$ & $\lambda_{1}(\mathrm{~nm})$ & $\lambda_{2}(\mathrm{~nm})$ & ${ }^{n_{\mathrm{p}}(\%)}$ \\
\hline 10 & 300 & 722 & 1318 & 43.6 \\
$10^{2}$ & 350 & 722 & 1325 & 43.6 \\
$10^{3}$ & 400 & 722 & 1325 & 44.6 \\
$10^{4}$ & 450 & 722 & 1327 & 46.4 \\
& 500 & 722 & 1339 & 49.3 \\
\hline
\end{tabular}

\subsection{Mulclphulou Systerns}

The results of the ootimization routine have been listed (Table 3 ) to illustrate the effect of the number of photons on the band-gap wavelengths and net power efflelency. Because the optimization routine does not calculate absolute maxima, there may be minor fluctuations in computed wavelength combinations and corresponding changes in efficlencles for higher order ( $1 . e ., n>5$ ) calculatlons, depending on the initial conditions. However, the absolute maxima for these cases need not be determined to exhibit the trends within the total data array. For instance, there exists a maxinun $n$ which appears to be $\sim 60 \%$, a vaiue whilh is approached asyorotically with Increasing number of photosystems (Figure 1). 


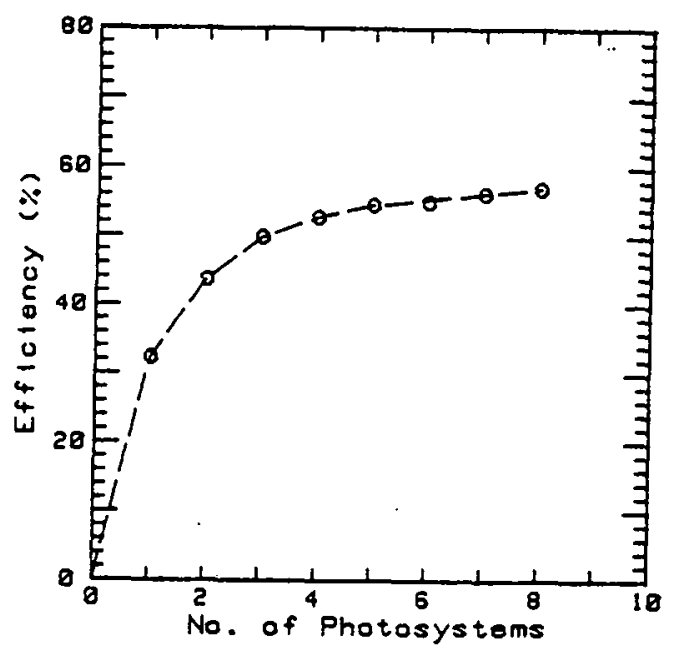

Fiz. 1. Theoretical power efficlencies $\left(n_{p}\right)$ for 1-8 ideal photosystems.

These data suggest that in a functional device there will be a trade-off, probably around 2-4 photosystems, between the complexity Imposed by an additional absorber and the net galn in efficlency.

Table 3

Optimum Wavelength Combinations and Corresponding Thermodynamic Efficlencles (AM1.2, $300 \mathrm{~K}$ )

\begin{tabular}{|c|c|c|c|c|c|c|c|c|c|}
\hline$n$ & & & ptime & un $\mathrm{W}$ & Vave 1 & engths & $s \quad(n m$ & & $n_{p}(\%)$ \\
\hline 1 & & & & & & & & 843 & 32.3 \\
\hline 2 & & & & & & & 722 & 1318 & 43.6 \\
\hline 3 & & & & & & 581 & 836 & 1333 & 49.7 \\
\hline 4 & & & . & & 510 & 669 & 853 & 1340 & 52.6 \\
\hline 5 & & & & 505 & 5649 & 831 & 1081 & 1355 & 54.4 \\
\hline 6 & & & 490 & 620 & 778 & 997 & 1189 & 1368 & 54.9 \\
\hline$i$ & & 479 & 583 & 715 & 8840 & 1024 & 1187 & 1378 & 56.2 \\
\hline 8 & 436 & 518 & 611 & 119 & 852 & 1040 & 1268 & 1397 & $37 . ن$ \\
\hline
\end{tabular}

is the number of photosystems is increased, there is a strong blue shift in the optimal wavelength of the first photon. This is not, however, the case for the wavelength of the last ohoton $\left(\lambda_{2}\right)$, which shows only a slight ret shift from 1318 to 1397 an on progression Erom 2 to 8 photons. A comparison of the data in Table 3 with the solar spectrum (Fig. 2) nrnvides a ingiral explanation for the rinimal trend in $\lambda_{n}$; for wavelengths longer than about 1380 nm, atmospheric condictons attenuate the photon flux, thus precluding the possibility of further enerzy gain with increasing wavelength.

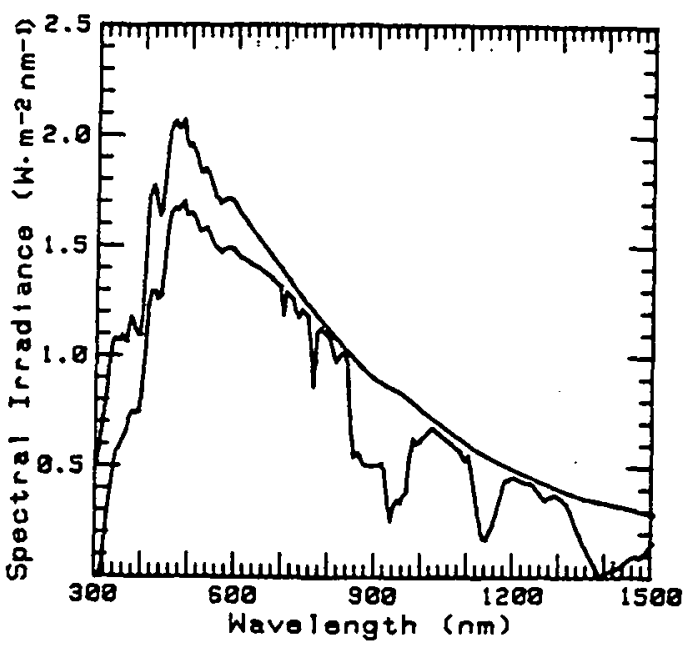

Fig. 2. Solar emission spectra at AMO and Al1.2 (a fter Böer, Ref. 3).

Ireland, et al. (4) have treated the case of cascaded cells $(n-2,3,5,7)$, each with a discrete, narrow spectral response, and have calculated the maxtrum efficiencies as a function of the lowest band-gap energy. Although the calculated maxima were not presented, their graphical results (which were based on an assumed quantum efficlency of 0.9 as contrasted with 1.0 which we have assumed here) are in reasonable agreement with our data.

\section{CONCLUSIONS}

These multiphoton efficlencles represent theoretical thermodynamic limits which can be approached only with power conversion systems such as cascaded photovoltalc devices. The optimum wavelengths reported here should be useful in the design of such cells (6). In photochemical systems, for which energy storage is an important criterion, the optimum wavelengths and theoretical linits will differ considerably from the values 11sted in Table 3. As Bolton (2) has shown, the inherent chemical efflciency of a singlebatulyap yuallitu-convelision device nuot be lower than the corresponding power efficlency. In addition, preliminary calculations on the storage efficiency of two-photon systems show that the effective band-gaps are significantly blue-shifted.

To date, our calculations have considered only AMl.2 solar flux data. For higher alr mass, we anticipate further decreases in theoretical efficlencles accompanied by spectral shifts of the optinal wavelengths.

\section{ACKNONLEDGEMENTS}

J.R.R. thanks the Vatural Sciences \& Englneering Research Council of Canada for 
inanctal support. We also thank Yarshall 3uhl of the SERI Computer Services Branch for his support in programming the multi-photon optinization codes.

6. REFERENCES

1. Ross, 2. T. and Hsiao, T.-L., J. Appl. Phys. 48, 4783 (1977).

2. Bolton, J. R., Sclence 202, 705 (1978).

3. Böer, K. W., Sol. Energy 19, 525 (1977).

4. Ireland, P. J., Wagner, S., Kazmersk1, L. L., and Hulstrom, R. L., Sclence 204 , $611(1979)$.

5. Evkhoff, P.. "System Identification: Paraneter and State Estimation", Wiley Interscience (1974) pp. 164-165.

6. Nelson, N. J., Johnson, K. K., Moon, R. L., Vander Plas, H. A., and James, L. W., Appl. Phys. Lett. 33, 26 (1978). 